\title{
Writing Instruction in Secondary Schools: Unraveling Practices and Challenges
}

\begin{abstract}
In a discourse related to teaching writing in second or foreign language classrooms, there is a focus on process writing which seems still new practice in many Nepali classrooms. In this context, this study was conducted to explore secondary level English teachers' practices and challenges of teaching writing. The study adopted qualitative research design. For this, twenty secondary level English teachers from both public and private schools of Sunsari District,Nepal were selected as informants. The data were collected through classroom observation, semi-structured interview and Focused Group Discussion (FGD). First, classroom observation of eight teachers was carried out followed by semi-structured interview. Then, the other twelve teachers were invited for FGD. Analysis of qualitative data uncovered that majority of the teachers adopted product approach to teaching writing with abundant stress on support to students for securing good marks in the final examination. The major challenges revealed behind this situation were large class size, low proficient learners, pressure on course completion, lack of practical training for teachers, and insufficient resources including ICT facility in the classroom contexts.
\end{abstract}

Keywords: collaborative writing, resource, writing challenge, writing instruction, writing process

\section{Introduction}

Getting mastery over writing skill is highly challenging. This skill is problematic to both L1 and L2 learners. In this context, Silva (1993) asserts, "both L1 and L2 writers employ a recursive composing process, involving planning, writing, and revising, to develop their ideas and find the appropriate rhetorical and linguistic means to express them" (p. 657).For L2 learners, learning to write in the target language is demanding because they have to pay due attention to several aspects of writing so as to compose a comprehensive text. In this regard, Richards and Renandya (2010) maintain, "L2 writers have to pay attention to higher level skills of planning and organizing as well as lower level skills of spelling, punctuation, word choice, and so on"(p. 303). It portrays that learning to write accurately is a complicated activity mainly for L2 learners.

Some studies have unfolded the impact of comprehensive techniques for writing instruction leading to enhance students' ability to write (Bai, $\mathrm{Hu}, \& \mathrm{Gu}, 2013$ ).EFL learners cannot cope with this complex aspect of learning independently. Especially, learners with low writing ability and writing disabilities require careful support by school, parents and community (Graham, Harris \& Larsen, 2001).In this manner, teacher's sensible conduction of writing tasks is crucial that affects seriously on students' learning on writing (Corneille, 2017).It depicts that teachers have an important role to facilitate L2 learners to acquire skills needed to improve their writing skill. Regarding the importance of writing instruction, Graham and Perin (2007) recommended to apply explicit writing instruction to support mainly the learners with writing difficulty in the areas of planning, revising, and editing to improve quality of their writing. From 
this discussion, it can be inferred that systematic and careful writing instruction can be crucial to enhance L2 learners' writing skill. Thus, it is essential for the teachers to be enlightened with the most appropriate approach and strategies to employ in their writing class.

As writing skill is essential for the future academic and career path of the learners, an effective classroom instruction targeted for developing writing would prove to be fundamentally important. Teachers' practices in teaching writing and the challenges they encounter in diverse contexts deserve significance for research. And the research findings would contribute to the understanding of underlying gaps between the intended curricular goals and classroom practices, which will finally be relevant for future policy and practice initiatives.

\section{Review of Literature}

Numerous approaches have emerged in the field of writing instruction. In the context of Asian L2 writing instruction, product approach to writing has been adopted by many English teachers (Pennington, Brock \&Yue, 1996). This approach to writing is concerned with the aim of writing task and its final product (Harmer, 2007). Learners in this approach are guided to focus on the structure provided to produce quality final product. However, a paradigm in writing instruction shifted when a term 'process' appeared first in the literature of 'L1 composition' derived from John Dewey's concept of learning as a process (Berlin, 1987, as cited in Susser, 1994).In this approach, the students undergo through multiple stages before they construct their composition (Harmer, 2007). The students, in this approach, can apparently avail exhaustive platform to exercise their writing skill. In this regard, Ho (2006) discusses opportunities the students have in process approach where they are guided step by step through several stages of process writing developing their confidence to improve quality of their composition. In the recent days, we can witness presence of genre-based approach to writing in the literature of writing instruction (Richards \& Renandya, 2010). This approach, "provides students with ample opportunities to become aware of the different purposes of written communication and the different ways information is organized in written texts" (Richards \& Renandya, 2010, p.304). In genre approach to writing, the learners perform numerous roles through writing in the real world.

A number of empirical studies have been carried out related to teaching writing in EFL contexts. The study of Shi (1998) uncovered that prewriting discussion contributed to improve students' writing in the areas of length of essays and vocabulary use. Another study by Storch (2005) disclosed majority students' positive attitude towards the experience of collaborative writing. Further, she also unveiled that collaboration in writing process was found to be advantageous for the students to generate ideas and provide feedback to their peers. Similarly, an investigation of Ho (2006) revealed process approach as an effective approach to foster confidence and writing ability in the students. In the same way, the examination of Kamimura (2000) and Hasan and Akhand (2010) about the effectiveness of product and process approach unearthed that balance between product and process can best facilitate L2 learners to develop their writing skill. From these investigations, it can be deduced that the L2 learners will be benefited by collaborative writing activities balancing product and process approach. 
In the context of Nepal, the Secondary Level English Curriculum has envisioned equal focus of all four language skills (CDC, 2014). Its focus is to "create opportunities for learners to learn together to draw on their personal life and language experiences, and to develop their social and cultural understanding" (CDC, 2014, p. 69). The curriculum has stated to apply pair and group work as crucial tools to foster high levels of participation. Further it has envisaged to "scaffold learners' language learning through the careful design of follow-up tasks which create opportunities for learners to practice in authentic contexts" (CDC, 2014, p. 69). In regard to writing instruction at secondary level education (in grade nine and ten), the present curriculum has allocated 35 per cent weightage for teaching writing (listening 10\%, speaking $15 \%$ and reading 40\%) (CDC, 2014). For writing instruction, the curriculum has clearly recommended to implement writing process: planning, drafting, revising and producing the final draft (CDC, 2014). Importantly, to support the teachers, a teacher guide has been developed which has clearly mentioned step by step processes to teach writing for the teachers so that they can facilitate writing instruction in line with the vision of the curriculum.

Some existing literature related to writing instruction shows significance of collaborative writing process in EFL writing instruction. Furthermore, it has been devised to engage the students into various stages of writing process before producing the final draft to strengthen their writing skill. Moreover, it also presumes blend of both process and product approach enhances L2 learners' writing skill.

However, particularly in secondary classrooms of Nepal, it is observed that the students are found reluctant to write when they are asked which requires some writing tasks. Mostly, they are found uninterested for spending some time to generate ideas related to their writing task collaboratively. Moreover, they are not interested for the peer-feedback to produce the final product incorporating suggestions of the peers and teacher. In this context, a study of Sapkota (2012) demonstrated positive impact of peer and teacher correction in students' writing. Especially, peer and teacher correction improved grammatical accuracy, coherence and cohesion in students' writing. In such situation, although the policy of Nepali secondary education curriculum and some literature related to teaching writing have emphasized the importance of collaborative writing process in teaching writing, many secondary level students lack this experience in their writing development. It illustrates a gap between policy and practice of teaching writing at secondary level. In Nepal, only a few studies have been conducted related to writing development in students. Nonetheless, classroom practices of teaching writing in line with the provision of curriculum in secondary schools of Nepal have still not been disclosed systematically. Thus, this study was administered to explore how secondary level English teachers of Nepal discharge their writing lesson, and what problems they have been facing to teach writing. In this rationale, this study addressed the following research questions:

- How is writing taught at secondary level?

- What challenges have the teachers been facing for teaching writing at secondary level?

\section{Methodology}

The present study adopted qualitative research design because this design provides the researcher with an opportunity to explore organizational reality and perspectives of the people involved (Jonker 
\& Pennink, 2010). For this study, I purposively selected twenty secondary level English teachers from public and private schools of Sunsari District, Nepal. They were chosen in terms of their willingness to participate in this research project. Majority of them possess minimum of four years teaching experience to twenty-two. All of them hold at least Bachelor's Degree in major English. For collecting data, I drafted semi-structured classroom observation form and the questions for semi-structured interview and FGD. Then, I tested the tools using them with the other teachers possessing similar tenets with the selected participants. Then, I improvised the tools incorporating feedback attained from the prior execution of the tools. After that, I visited eight secondary schools (four public, four private) and received oral consent from the principals and English teachers to conduct classroom observation and interview. I informed each selected secondary English teacher to prepare a lesson to teach guided/free writing in their natural way. Hence forth, I observed writing lessons of eight English teachers using semi-structured observation form followed by semi-structured interview. The semi-structured interview was recorded using an audio recorder. Afterwards, I invited twelve secondary English teachers (six public, six private) for FGD who were participants of a professional gathering. Receiving oral consent from them, FGD was conducted. Note taker and audio recorder were managed to record the data of FGD. The recorded data of both semistructured interview and FGD were transcribed and sent to the participants to check the accuracy of transcription. The confidentiality of the participants in qualitative research is very sensitive (Creswell, 2012). The ethical matter was highly valued in this study. All the responses from the teachers were kept confidential. The data were recorded with the oral consent from all the participants. Further, respondents' privacy was strongly maintained using codes instead of their names. Furthermore, the transcribed script was sent to each interviewee to obtain their acceptance and assess validity of the transcription.

\section{Results and Discussion}

This section presents results and discussions drawn from thematic analysis of classroom observation, semi-structured interview and FGD. The qualitative data were analyzed employing 'Thematic Analysis' process proposed by Braun and Clarke (2006). The first research question was answered with the analysis of classroom observation, semi-structured interview and FGD, and generated a broad theme, 'Practice of writing instruction' and a sub- theme 'Use of materials in writing instruction'. The second research question was addressed by the analysis of semi-structured interview and FGD, and developed the next theme, 'Challenges of teaching writing' and a sub- theme 'Support for teachers to empower their writing instruction skills.'

\section{Practice of Writing Instruction}

Analysis of the qualitative data disclosed that almost all the teachers followed product approach to teaching writing. Almost all the teachers write lesson topic on the board to commence their writing lesson. They explain a topic, and format or structure of writing task. After that, they explain each part of writing topic in detail. Then, they explain how to write different parts of writing topic presenting some writing samples. After the students complete their writing, the teachers either ask the students to read out their writing or check their writing themselves making corrections of some grammatical errors. If the 
students cannot complete their writing task within the period, the teachers assign the task to the students as homework. And the next day the teacher makes correction of the students' writing. Regarding writing process, T8 shares his experience as:

Being a private school teacher, I should focus on marks. So, I teach practically how my students can score more in the exam. First of all, I create environment for the writing item to be taught. For that, I present a number of examples with the hints so that the students will know what writing item they are going to read. And I also provide them with necessary vocabulary and some structures as well. Then, I assign the writing topic to the students. Then, the students write on the given topic. After the students complete their writing, I see their writing and provide them some necessary feedback.

This shows that the writing lesson the teachers deliver in their writing class is influenced by examination. Moreover, the teachers adopt such activities in their class that ensure students get good marks in the final examination. Also, the teachers themselves provide ideas, vocabulary items and structure to the students that are needed to compose a written text. It clearly outlines that various important stages of writing development (prewriting discussion, planning, drafting, revising and rewriting) are excluded in the writing class.

Nevertheless, in the classroom observation, some of the teachers were found involving the students in generating ideas and vocabulary collaboratively. They ask the students to work in groups to write collaboratively. And share their ideas with the other groups. However, they were unable to engage the students into all stages of teaching writing (pre-writing, drafting, revising, editing and producing the final draft). Only a few number of teachers involved the students in peer correction. Almost all the teachers did not involve the students to revise, edit and rewrite.

All the teachers accorded that they have to support the students to write topic sentence, thesis statement, supporting details, conclusion of different writing items. Their conception resembles with the outcome of Shi's (1998) study that involvement of the students into different prewriting discussion activities develops writing of the students. However, it has been found from the classroom observation that they explained such concepts orally making the students listen passively. The teachers did not engage the students practically to enable them to write such components in their compositions.

It was also observed that almost all the teachers were found unable to engage the students in all stages of writing development. The students were partially involved in generating ideas. But almost all the teachers did not involve the students in revising, editing and rewriting process. The main focus of the teachers was on drafting. For supporting the students to organize their composition, the teachers explained all the parts of the writing tasks. However, their long explanation was not supported with concrete examples and practical activities to engage the students.

The students should be enlightened with the value of reading in writing process as guiding students to read and research on writing tasks enables them to write efficiently (Grabe \& Zhang, 2013). Conversely, majority of the teachers do not provide an opportunity for students to read and research about unfamiliar writing topics. Instead, they explain the topics themselves for the students. It implies that the students do not get opportunity to exercise their researching skill from their school level. 
Overall, the analysis of classroom observation, semi-structured interview and FGD reveals that the majority of Nepali secondary English teachers employ product approach to teaching writing. This illustrates that the current practices of teaching writing is incongruent with the policy of secondary education curriculum, recommendations of the TG, scholarly publications on academic writing (e.g. Bailey, 2011; Leki, 2010) and the findings of the studies in EFL writing instruction (e.g. Kamimura, 2000; Storch, 2005; Ho, 2006; Hasan \& Akhand, 2010) which focus on collaborative writing process balancing process and product approach to teaching writing.

\section{Uses of Materials in Writing Instruction}

All the teachers maintained that materials are essential for teaching writing. Further, they conceived that their activities of writing lesson should align with the spirit of the curriculum and suggestions of the TG. Majority of the teachers both from private and public schools have been using textbook as the most dominant teaching resource. Despite this, the other resources the majority of the teachers consult are: practice book, resource books, newspaper cut outs, and some online resources.

However, it has been unveiled that the majority of the teachers do not consult and study the curriculum and the TG. The TG developed by the CDC has presented step by step suggestions to teach all the lessons of the book available online in free of cost. Sadly, many teachers have even not found the TG. Mostly, many private schools' teachers even stated that they are unknown to the TG produced by the CDC for the teachers. In this regard, T5 states," I have not found the Teacher's Guide. I asked many times to the school administration. I have searched to find it but I could not open it through the website." Likewise T8 asserts, "Since I have been teaching for a number of years and yes caring about the SEE (Secondary Education Examination) question patterns, I take necessary methods myself. I hope they are related to curriculum." This situation outlines that the teachers are not consulting the curriculum and TG to plan and present their writing lessons in the classroom.

From this discussion, it seems that majority of the teachers base their writing lesson on the textbook. Still, many teachers possess inadequate technological skills to search, plan and present materials using ICT.

\section{Challenges of Teaching Writing}

The participants in the semi-structured interview and FGD responded that they have been encountering multiple complexities to teach writing in their class. Firstly, the major problem the teachers should cope with in their writing instruction process is insufficient time. (Harmer, 2007). In case of private schools, 35-40 minutes time has been allocated for teaching English, for public schools 45 minutes. Within this short period of time, it is almost impossible to engage the students into different stages of teaching writing. In this manner, T6 resonates:

Time is not sufficient especially for teaching writing. I have to always take more time, 5-10 minutes of another period. Because of lack of time, it is not possible to complete the writing tasks during the different activities like dividing the students into different groups, extracting or collecting their ideas, and talking about different mechanisms of writing, the time is not sufficient to do all these activities. 
Secondly, one of the concerns the teachers have been facing every day in their writing lesson is size of the class (Leki, 2001). The majority of Nepali teachers have been experiencing a problem of large class. Some teachers even have 80 plus students in their class. In such case, the teachers have been unable to make their writing instruction participatory. In this connection, T5 mentions, "There are more number of students in classes. And it is very difficult to control the students." To cope with this situation, training teachers with strategies to engage students into various collaborative classroom activities could be pragmatic.

Thirdly, the practice of teaching English in majority of Asian countries is still "traditional productoriented examination-centered approach" (Pennington et al., 1996, p. 228). English teachers in Nepal do have similar situation. They encounter a huge pressure to complete the course so earlier so that they have enough time to practice and revise the course for the final examination. The teachers are also mainly concerned with supporting the students to obtain good marks in the final examination. Thus, the teachers adopt such strategies that could enable their students to secure high marks in the examination. In this matter, one participant of FGD says, "Actually our students are exam oriented. They want to learn the things that will appear in the examination. This is the reason why students are not much interested in learning all the processes of writing." This illustrates that the teachers conduct classroom activities to enable their students to secure better score in the examination.

Fourthly, the next burning issue the teachers are facing is inadequate instructional resources. Majority of the teachers have been using textbook and practice book as primary resources in the class. Despite these, majority of the teachers are not using the other materials. Many teachers are even not using the curriculum and the TG. In this context, T7 says, "We do not have sufficient materials to support students to improve their English."Likewise, T3 also holds similar thought stating, "We have got lack of materials. There is not such hard and fast materials that we can get for teaching writing." It implies that the teachers should be provided with required resources to make their writing instruction effective.

Another issue both public and private schools' teachers are facing is unavailability of ICT tools. Most of the classes observed lacked facility of ICT. Hardly, teachers get chance to make PowerPoint presentations and show videos to the students about the topics which could be best presented using such tools to make concepts clear. Equally, many teachers lack technological skill to make the effective use of available technological tools. Regarding a problem of modern technology, T4 says:

There is no access of the internet in my school. I lack training to use ICT in the classroom. There is a multimedia projector in my class, but I don't have much idea to use that ICT technology in my class. The main issue the public schools' teachers are facing is low level proficiency of the students.

Majority of the students are found poor in vocabulary, grammar and content. Thus, teaching writing is the most challenging job for the teachers because (in the words of T7):

Most students have poor proficiency of English. They do not have sufficient vocabulary. They are using means of communication mostly Nepali. They don't have language structure as well. They are not correctly using even a single sentence. They do not have command over English.

Interestingly, the students of the private schools have better command over English, since the medium of instruction in those schools is English. However, the majority of the private schools' teachers admitted 
that the students do not pay proper attention to English. In this context one participant of FGD states, "The private schools' students neglect English and pay more attention to the other subjects, e.g. math, science, etc. They think English subject is easier for them." This circumstance makes learners ignorant to valuable stages of writing development. Thus, it seems necessary to empower the teachers to plan and implement learner centered activities in their classrooms to teach writing.

\section{Support for Teachers to Empower their Writing Instruction Skills}

All the teachers asserted that it is important to engage the students into different stages of collaborative writing process. Importantly, all the teachers asserted that they are willing to apply those stages in their writing lesson. In this regard, one participant of FGD states:

In this process the students get chance to learn from the other students' writing, they can get chance to correct their work getting feedback from their friends. Similarly, they repeat their writing; they reread their writing, so that it will be quite good while producing the final draft.

However, to enable the teachers to make their writing lesson collaborative, engaging and productive, they should be supported in multiple dimensions.

First, all the teachers said that they need frequent training on how to make their writing instruction effective. Here, in this circumstance, T1views, "I expect some effective training conducted by different organizations so that we can know the depth of these writing items and we can conduct teaching learning activities accordingly." Moreover, many teachers stated that they need training on ICT so that they will be able to use ICT in their writing class.

Secondly, majority of the teachers maintained that they do not have enough materials. In this matter, T3 states, "We have got lack of materials. There are no such hard and fast materials that we can get for teaching writing." Even many teachers have not found the curriculum and the TG. In this context, it seems mandatory to provide necessary materials and resources to the teachers to empower them to make their writing instruction effective.

Thirdly, most of the teachers are facing short of time. In this regard, one participant of FGD says, "We have (in private school) 35-40 minutes class. So there should be change in time. At least 60 minutes class should be managed to involve the students into all the phases of process writing."Here, it seems that the time allocated to teaching English in general and writing in particular should be revised.

Likewise, some teachers believe that their exposer to some model classes - practically teaching writing to the students in the real classroom could help them to attain valuable insightsfor teaching writing. In this context, T4 stresses, "I strongly need model class conducted in my class from the expert." In this context, an exposure to a model class that demonstrates practically how to engage students into all the stages of writing lesson collaboratively can be instrumental for the teachers to enhance their writing instruction skills. 


\section{Conclusion and Implications}

The findings of this study evoked that majority of secondary level English teachers followed product approach to teaching writing to facilitate the students to secure more marks in the final examination. Although interpretation of qualitative data portrayed teachers' desire to implement collaborative writing process in their writing class, they encountered multiple complexities for this condition: large class size, pressure to complete course on time, low proficiency level of the learners, lack of instructional materials, training and ICT. This clearly depicts disparity between policy and actual classroom practices of writing instruction in secondary schools of Nepal.

From the above discussions, it can be claimed that the challenges the secondary English teachers of Nepal have been facing in writing instruction in their classroom cannot be resolved by their sole efforts. Thus, while framing a policy related to teacher development, focus can be given to process writing as opposed to product writing. Moreover, comprehensive training programme should be constituted and implemented practically embedding ICT contents so that the teachers can blend ICT in their writing class. Further, all the schools should be supported with sound access to ICT along with instructional resources and materials so that the teachers would have favorable condition to adopt process- based collaborative writing instruction strategies in their writing class.

Finally, this study is limited in many respects: in terms of respondents, classroom observation and follow up interview, and a number of FGDs. In this manner, execution of further comprehensive studies is imperative to draw broader generalizations to bridge the gap between policy and practice of writing instruction in secondary schools of Nepal.

\section{References}

Bai, R., Hu, G., \& Gu, P. Y. (2013). The relationship between use of writing strategies and English proficiency in Singapore primary schools. The Asia-Pacific Education Researcher, 23(3), 355-365. doi:10.1007/s40299-0130110-0

Bailey, S. (2011). Academic writing: A handbook for international students (Third ed.). New York, NA: Routledge.

Braun, V., \& Clarke, V. (2006). Using thematic analysis in psychology. Qualitative Research in Psychology, 3(2), $77-$ 101. doi:10.1191/1478088706qp063oa

Corneille, T. S. (2017). Evaluating the teaching of writing in advanced EFL classes in the context of competency-based approach: Case of some secondary schools of Benin Republic. International Journal of English Research, 3(2), 68-75. Retrieved from www.englishjournals.com

Creswell, J. W. (2012). Educational research: Planning, conducting, and evaluating quantitative and qualitative research (Fourth ed.). Boston, MA: Pearson.

Curriculum Development Centre (CDC) Nepal. (2014). Secondary education curriculum of Nepal class 9-10 part one. Sanothimi: Author.

Curriculum Development Centre (CDC) Nepal. (2017). Teacher's guide English grade 10. Sanothimi: Author.

Grabe, W., \& Zhang, C. (2013, March). Reading and writing together: Critical component of English for academic purposes teaching and learning. TESOL Journal, 4 (1). doi:10.1002/tesj.65

Graham, S., \& Perin, D. (2007). Writing next: Effective strategies to improve writing of adolescents in middle and high schools - A report to Carnegie Corporation of New York. Washington, DC: Alliance for Excellent Education.

Graham, S., Harris, K. R., \& Larsen, L. (2001). Preventionand intervention of writing difficulties for students with 
learning disabilities. Learning Diasbilities Research \& Practice, 16(2), 74-84.

Harmer, J. (2007). The practice of English language teaching (fourth ed.). Harlow: Pearson Education Limited.

Hasan, M. K., \& Akhand, M. M. (2010). Approaches to writing in EFL/ESL context. Journal of NELTA, 15, 77-88.

Ho, B. (2006). Effectiveness of using the process approach to teach writing in six Hong Kong primary classrooms. Perspectives: Working Papers in English and Communication, 17(1), 1-52. Retrieved from citeseerx.ist.psu. edu

Jonker, J., \& Pennink, B. (2010). The essence of research methodology: A concise guide for master and PhD students in management science. New York, NA: Springer.

Joshi, B. R., Dhungana, P., \& Pandit, C. K. (2017). English grade 10. Sanothimi: Curriculum Development Center.

Joshi, B. R., Joshi, L., \& Dhungana, P. (2016). English grade 9. Sanothimi: Curriculum Development Center.

Kamimura, T. (2000). Integration of process and product orientations in EFL writing instruction. RELC Journal, 31 , 1-29. doi:10.1177/003368820003100201

Leki, I. (2001). Material, educational, and ideological challenges of teaching EFL writing at the turn of the century. IJES, 1(2), 197-209.

Leki, I. (2010). Academic writing: Exploring processes and strategies (Second ed.). New Delhi: Cambridge University Press.

Pennington, M. C., Brock, M. N., \& Yue, F. (1996). Explaining Hong Kong students' response to process writing: An exploration of causes and outcomes. Journal of Second Language Writing, 5(3), 227-252. doi:10.1016/S10603743(96)9000-X

Richards, J. C., \& Renandya, W. A. (2010). Methodology in language teaching. New Delhi: Cambridge University Press.

Sapkota, A. (2012). Developing students' writing skills through peer and teacher correction: An action research. Journal of NELTA, 17, 70-82.

Shi, L. (1998). Effects of prewriting discussions on adult ESL students' compositions. Journal of Second Language Writing, 7(3), 319-345. doi:10.1016/S1060-3743(98)90020-0

Silva, T. (1993). Toward an understanding of the distinct nature of L2 writing: The ESL research and its implications. TESOL QUARTERLY, 27, 657-677.

Storch, N. (2005). Collaborative writing: Product, process, and students' reflections. Journal of Second Language Writing, 14(3), 153-173. doi:10.16/j.jslw.2005.05.002

Susser, B. (1994). Process approaches in ESL/EFL writing instruction. Journal of Second Language Writing, 3 (1), 31-47. doi:10.1016/1060-3743(94)90004-3

\section{Appendix A}

\section{Observation Record Form}

Name of a teacher:

Subject:

Name of a school:

Date:

Qualification: Time: No. of Students: Topic of the lesson: Focus of the lesson:

\begin{tabular}{|c|c|c|c|c|c|}
\hline Prewriting activities & Drafting & Revising & Editing & Producing the final draft & Use of materials \\
\hline & & & & & \\
\hline & & & & & \\
\hline & & & & & \\
\hline
\end{tabular}




\section{Appendix B}

\section{Interview Questions for the Teachers}

1. Do you think writing process (pre-writing, drafting, revising, editing and producing the final draft) is important for students? Why?

2. Is it necessary to engage the students into different stages of teaching writing in your class? Why?

3. Is it necessary to support your students to write topic sentence, thesis statement, supporting details, conclusion of paragraph, essay, etc.? Why?

4. Why are you unable to engage your students into different stages of teaching writing in your writing class?

5. Are instructional materials important for classroom teaching? Why?

6. What materials have you been using to teach writing in your class regularly?

7. Do you study the teacher's guide and the curriculum produced by the Curriculum Development Centre available online freely as supporting materials for your writing instruction? If not, why?

8. What problems have you been facing for teaching writing in your class?

9. What support do you need in order to improve your skills of teaching writing?

\section{Appendix C}

\section{Focused Group Discussion questions}

1. How do you teach writing in your class regularly?

2. Do you think writing process (pre-writing, drafting, revising, editing and producing the final draft) is important for students? Why?

3. Is it necessary to engage the students into different stages of teaching writing in writing class? Why?

4. Is it necessary to support your students to write topic sentence, thesis statement, supporting details, conclusion of paragraph, essay, etc.? Why?

5. Are you able to engage your students into different stages of writing development in your writing class? If not, why?

6. Are instructional materials important for classroom teaching? Why?

7. What materials have you been using in your writing class?

8. Have you been studying teacher's guide and the curriculum produced by the Curriculum Development Centre available online freely as supporting materials for your writing instruction? If not, why?

9. What challenges have you been facing to teach writing in your class?

10. What support do teachers need to improve their skill of teaching writing at secondary level?

Tirtha Karki is an Assistant Lecturer of English Education at Janta Multiple Campus, Itahari, Sunsari, Nepal. He has also been working as a freelance teacher trainer for seven years at NELTA, British Council Nepal and Educational Training Centre, Sunsari, Nepal. He is a Vice president of NELTA Province No. 1. His research interests are second language writing and teacher education. 